\title{
Lateral differences in Ki-67 in breast cancer
}

\author{
ALEXEY PETROVICH DMITRENKO
}

\author{
State Budgetary Institution of Public Health Services of The Rostov Region, \\ Oncologic Dispensary, Rostov-on-Don 344006, Russia
}

Received December 3, 2015; Accepted March 23, 2016

DOI: $10.3892 / \mathrm{mco} .2016 .845$

\begin{abstract}
Morphological features of right- and left-sided breast cancer (BC) have been rarely studied. Ki-67 is an independent predictive marker for a local relapse, and for overall and disease-free survival. In previous literature, lateral differences in $\mathrm{Ki}-67$ in $\mathrm{BC}$ have not been reported. Using immunohistochemical analysis, the biopsy material of 500 patients was investigated. Four BC parameters were investigated: The expression levels of the estrogen receptor (ER), progesterone receptor (PR), Ki-67 and Her-2-neu. A comparative analysis of $\mathrm{Ki}-67$ in groups with right- and left-sided $\mathrm{BC}$ was performed. Lateral differences in Ki-67 in three age groups, $\leq 49,50-59$ and $\geq 60$ years, were assessed. A higher expression of Ki-67 corresponded with right-sided $\mathrm{BC}(\mathrm{r}=-0.08 ; \mathrm{P}=0.046)$. Correlation of $\mathrm{Ki}-67$ with the age of the patient was characteristic only for right-sided $\mathrm{BC}(\mathrm{r}=-0.28 ; \mathrm{P}<0.001)$. The comparative analysis revealed that tumors from patients with right-sided $\mathrm{BC}$ aged $\geq 60$ years exhibited a lower Ki-67 index compared with tumors from patients aged $\leq 49(\mathrm{P}=0.003)$ and $50-59$ years $(\mathrm{P}=0.000013)$. In left-sided $\mathrm{BC}$, the $\mathrm{Ki}-67$ in the different age intervals revealed no significant difference. On performing an assessment of lateral differences for the different age intervals, it was established that the Ki-67 index of right-sided BC was significantly higher compared with the left-sided $\mathrm{BC}$ in two of the age groups, $\leq 49(\mathrm{P}=0.038)$ and $50-59$ years $(\mathrm{P}=0.047)$. In the $\geq 60$ years group, lateral differences in $\mathrm{Ki}-67$ were not revealed $(\mathrm{P}=0.4)$. The analysis of lateral differences in Ki-67 in tumors of various receptor profiles revealed significant differences in $\mathrm{Ki}-67$ of the right- and left-sided $\mathrm{BC}$ under $\mathrm{ER}^{+} \mathrm{PR}^{-}(\mathrm{P}=0.007)$ and $\mathrm{ER}^{-} \mathrm{PR}^{-}(\mathrm{P}=0.016)$ conditions. The reasons behind lateral and age differences of $\mathrm{Ki}-67$ are discussed.
\end{abstract}

Correspondence to: $\mathrm{Dr}$ Alexey Petrovich Dmitrenko, State Budgetary Institution of Public Health Services of The Rostov Region, Oncologic Dispensary, 9 Socolov Street, Rostov-on-Don 344006, Russia

E-mail: alex_dmitrenko@mail.ru

Abbreviations: $\mathrm{BC}$, breast cancer; ER, estrogen receptor; PR, progesterone receptor; CI, confidence interval

Key words: Ki-67, proliferative activity, breast cancer, laterality

\section{Introduction}

Features of right- and left-sided breast cancer (BC) have been poorly studied to date. Publications on lateral differences and the incidence of $\mathrm{BC}$ are few, and only a single study has been published on lateral differences and survival following BC (1-3). Results from population studies have indicated that the frequency of occurrence of left-sided $\mathrm{BC}$ is higher compared with right-sided BC (4-6). The distinction is not great (4-8\%), although the difference is not considered to be trivial, and may be associated with unidentified etiological factors (7).

The laterality of $\mathrm{BC}$ does not belong to recognized predictive factors. In a study performed by the Israeli Cancer Register, it was suggested that the survival of patients with $\mathrm{BC}$ is not dependent on tumor laterality (8). However, the results of other previous studies showed that the survival of patients with left-sided $\mathrm{BC}$ is higher compared with patients with the right-sided $\mathrm{BC}(9,10)$.

Studies on morphological differences of right-and left-sided $\mathrm{BC}$ are also few. Erendeeva et al (9) performed a comparative analysis of right- and left-sided BC on 45 clinico-morphological parameters. Results from this analysis revealed a number of statistically significant characteristics, including size of the primary center, histological type of tumor, existence of metastasis in regional lymph nodes and background pathology. This study established that primary tumors localized on the right side were significantly more in size compared with tumors of the left side, and had a significant tendency to metastasize in regional lymph nodes. Among the various forms of a mastopathy (background pathology), a particular emphasis was placed on the existence of mazoplasia, the significant processes of proliferation in breast tissue. It was noted that mazoplasia associated with right-side tumors was observed five times more often compared with left-side tumors. The authors considered that asymmetry of hormonal and immune influences in a human body could be the predominant reason for asymmetry of the clinico-morphological parameters of BC. Nouh et al (11) showed that metastases in regional lymph nodes of left-sided BC were observed less frequently compared with right-sided $\mathrm{BC}$. The authors hypothesized that this may be associated with the greater activity of the right hand.

Proliferative activity of a tumor defines its aggression, and is an indicator of the prognosis (12). A number of indicators of proliferative activity are known. The greatest interest in recent years has focused on the biomarker, Ki-67, as an index 
of proliferative activity. Numerous previous studies have shown that $\mathrm{Ki}-67$ is an independent predictive marker for a local relapse, and for overall and disease-free survival (13-23). No previous studies, to the best of our knowledge, have shown lateral differences in $\mathrm{Ki}-67$ in $\mathrm{BC}$. Research in this area may enrich our knowledge of the natural history of $\mathrm{BC}$ and assist in creating personalized treatment for this disease.

\section{Materials and methods}

Following the protocols of immunohistochemical research of the Rostov Regional Morphological Bureau (2008-2010), an analysis of biopsy material from 500 patients was performed. Four BC parameters were investigated: The expression levels of the estrogen receptors (ERs), of the progesterone receptors (PRs), of Ki-67 and the epidermal growth factor receptor, C-erbB-2 (Her-2-neu). From these 500 BC cases, right-sided localization of the BC was observed in 238 (47.6\%) patients; that of left-sided BC was observed in $262(52.4 \%)$ patients. The present study aimed to do the following: i) Perform comparative analysis of Ki-67 levels in groups of patients with right- or left-sided BC; ii) to define lateral differences of Ki-67 levels in three different age groups ( $\leq 49,50-59$ and $\geq 60$ years); and iii) to estimate changes in $\mathrm{Ki}-67$ levels, depending on other parameters (ER, PR, Her-2-neu).

The statistical analysis was performed with the use of Statistics 8.0 software (StatSoft, Inc., Tulsa, OK, USA). To define interrelations, correlation matrixes were created. Comparison of different groups was performed using Student's t-test. In the case of the small size of groups, Fisher's exact test was used. Comparison of averages was performed by analysis of variance. The data are shown as percentages, with $95 \%$ confidence intervals $(95 \% \mathrm{CI}) \pm$ the standard error of the mean. $\mathrm{P}<0.05$ was considered to indicate a statistically significant difference.

Production of immunohistochemical reactions and interpretation of the results were performed, according to a previous study (24). For the light optical and immunohistochemical experiments, biopsy material was fixed in $10 \%$ buffering (neutral) formalin (BlikMedicalProduction, Taganrog, Russia) within $24 \mathrm{~h}$ at room temperature. Following treatment with paraffin (BlikMedicalProduction), serial cuts $4 \mu \mathrm{m}$-thick were performed. The cut sections were mounted onto the subject glasses and were loaded or covered with poly-L-lysine (Sigma-Aldrich, St. Louis, MO, USA). For the light optical experiments, the cut sections were stained with hematoxylin and eosin (DakoCytomation, Hamburg, Germany). For the immunohistochemical experiments, the cut sections made from paraffin blocks were placed in the thermostat for $30 \mathrm{~min}$ at $56^{\circ} \mathrm{C}$. Paraffin was removed from the sections by incubating in xylol (BlikMedicalProduction) five times. The duration of one incubation was between 5 and $10 \mathrm{~min}$. The sections were subsequently dehydrated in three changes of absolute ethanol for $3 \mathrm{~min}$, prior to placement in distilled water. To visualize the proteins, the sections were incubated with buffered solution (DakoCytomation) of primary antibodies (DakoCytomation, Hamburg, Germany) in a water bath for $20 \mathrm{~min}$ at $95^{\circ} \mathrm{C}$. The tissue sections were subsequently washed in the buffer. Endogenous peroxidase activity was suppressed using a hydrogen peroxide-based blocking solution (DakoCytomation) for 5-7 $\mathrm{min}$ at room temperature.
Immunohistochemical reactions were performed in an automatic robotized device (Autostainer Plus; DakoCytomation) according to the following protocol: Incubation with primary antibodies (15-30 min, according to antibody protocol), incubation with secondary antibodies (30 min), incubation with a substratum chromogen $(8 \mathrm{~min})$ and staining of kernels with Mayer's hematoxylin (5 min). A Dako EnVision system and peroxidase (antirabbit, antimouse) was used. The sections were washed using Tris-HCl, containing Triton-X, to reduce background coloring and promote penetration of solutions into the tissue. For each studied gene, a negative control was used instead of primary antibodies, and also a positive control, the fabric which containing this antigen. The following mouse monoclonal antibodies were used: Anti-progesterone receptor (Clone PgR 636; Target Retrieval S 1700 pH 6.0; dilution 2:100), anti-Human Ki-67 (Clone MIB-1; Target Retrieval S $1700 \mathrm{pH}$ 6.0; dilution 1:100), all from DakoCytomation. HER-2/neu protein expression was performed using the HercepTest, according to the manufacturers instructions (DakoCytomation).

\section{Results}

The proliferative activity of Ki-67 significantly correlated with the $\mathrm{BC}$ laterality $(\mathrm{r}=-0.08 ; \mathrm{P}=0.046)$. A higher $\mathrm{Ki}-67$ index corresponded with right-side localization of the $\mathrm{BC}$. The $\mathrm{Ki}-67$ median for the right-sided $\mathrm{BC}$ was $18.1 \%(95 \% \mathrm{CI}=15.3-21.0)$ and for the left-sided $\mathrm{BC}$ was $14.5 \%(95 \% \mathrm{CI}=12.2-16.8)$. A t-test revealed the significance of differences $(\mathrm{P}=0.046)$.

Correlation of $\mathrm{Ki}-67$ with the age of the patients was characteristic only for right-sided $\mathrm{BC}(\mathrm{r}=-0.28 ; \mathrm{P}<0.001)$. The maximum $\mathrm{Ki}-67$ values for right-sided $\mathrm{BC}$ were observed in the age interval of 50-59 years $(25.3 \%$; 95\% CI=19.4-31.3) and the minimum $\mathrm{Ki}-67$ values were observed in the age interval $\geq 60$ years $(12.0 \% ; 95 \% \mathrm{CI}=9.1-14.8$; Fig. 1$)$. The comparative analysis revealed that tumors of patients with right-sided $\mathrm{BC}$ of an age interval $\geq 60$ years had a Ki-67 index significantly lower compared with tumors of patients at the age of $\leq 49(\mathrm{P}=0.003)$ and 50-59 years $(\mathrm{P}=0.000013)$. In the left-sided $\mathrm{BC}$, the Ki-67 index in age intervals did not significantly differ. An assessment of the lateral differences in age intervals established that the Ki-67 index of right-sided $\mathrm{BC}$ was significantly higher compared with left-sided $\mathrm{BC}$ in two age groups, $\leq 49(\mathrm{P}=0.038)$ and $50-59(\mathrm{P}=0.047)$ years. For the $\geq 60$ years age group, lateral differences in $\mathrm{Ki}-67$ were not observed ( $\mathrm{P}=0.4$; Fig. 2 ).

The analysis of lateral differences of Ki-67 in tumors of different receptor profiles revealed significant differences in Ki-67 of the right- and left-sided $\mathrm{BC}$ under $\mathrm{ER}^{+} \mathrm{PR}^{-}(\mathrm{P}=0.007)$ and $\mathrm{ER}^{-} \mathrm{PR}^{-}(\mathrm{P}=0.016)$ conditions, therefore, when there is no expression of PR. In these cases, the Ki-67 index was higher in right-sided BC (Table I). In general, the maximum Ki-67 index was found in the group of right-sided tumors with the $\mathrm{ER}^{-} \mathrm{PR}^{-}$receptor profile, where the Ki-67 index reached $33.7 \pm 5.1 \%$.

In tumors with the $\mathrm{ER}^{+} \mathrm{PR}^{+}$receptor profile, lateral differences of the $\mathrm{BC}$ on the Ki-67 index were absent $(\mathrm{r}=0.61)$. The assessment of the $\mathrm{ER}^{-} \mathrm{PR}^{+}$receptor profile was not performed due to insignificant numbers of samples. 
Table I. Ki-67 expression in right- and left-sided BC in different receptor profiles.

\begin{tabular}{|c|c|c|c|c|c|}
\hline \multirow[b]{2}{*}{ Receptor profile } & \multicolumn{2}{|c|}{ Right-side } & \multicolumn{2}{|c|}{ Left-side } & \multirow[b]{2}{*}{ P-value } \\
\hline & $\mathrm{n}$ & $\mathrm{Ki}-67(\%)$ & $\mathrm{n}$ & $\mathrm{Ki}-67(\%)$ & \\
\hline $\mathrm{ER}^{+} \mathrm{PR}^{+}$ & 136 & $11.4 \pm 3.2$ & 155 & $12.3 \pm 3.0$ & 0.610 \\
\hline $\mathrm{ER}^{+} \mathrm{PR}^{-}$ & 39 & $21.4 \pm 5.9$ & 37 & $9.5 \pm 6.1$ & 0.007 \\
\hline $\mathrm{ER}^{-} \mathrm{PR}^{+}$ & 10 & - & 1 & - & - \\
\hline $\mathrm{ER}^{-} \mathrm{PR}^{-}$ & 53 & $33.7 \pm 5.1$ & 69 & $22.2 \pm 4.5$ & 0.016 \\
\hline
\end{tabular}

- indicates when comparative analysis was not performed due to small case numbers. BC, breast cancer; ER, estrogen receptors; PR, progesterone receptors.

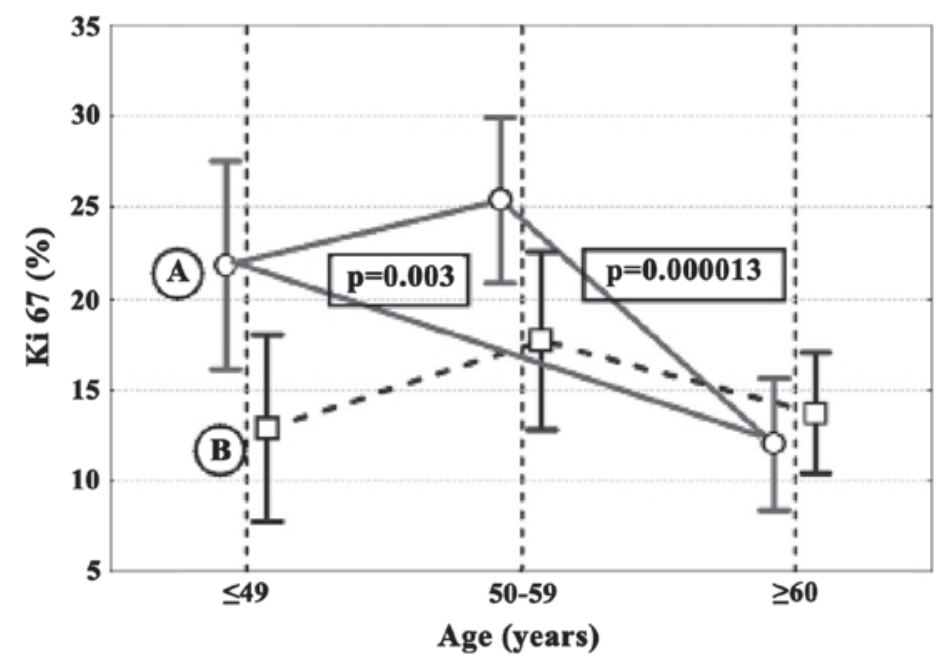

Figure 1. Comparative analysis of Ki-67 in breast cancer from patients at various ages in (A) right- and (B) left-sided breast cancer.

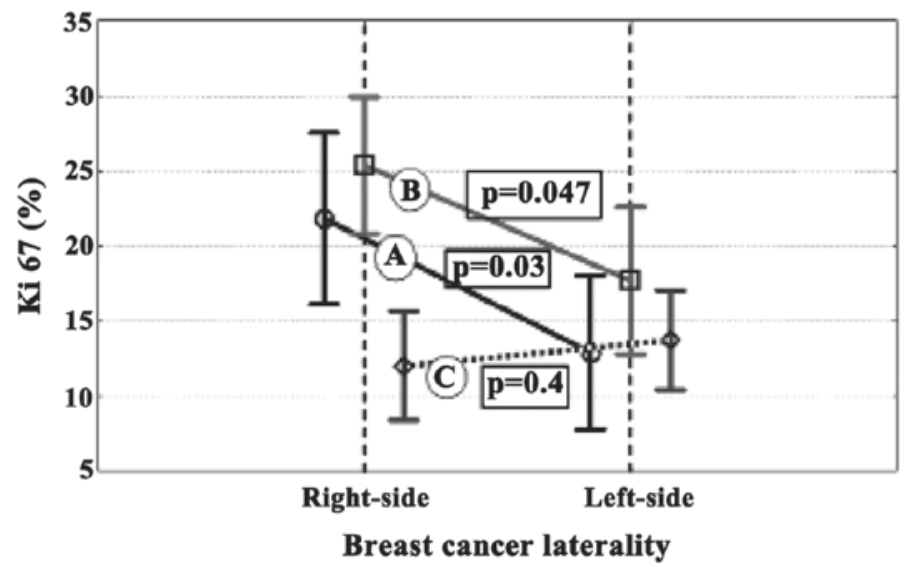

Figure 2. Comparative analysis of Ki-67 in right- and left-side breast cancer from patients aged (A) $\leq 49$, (B) 50-59 and (C) $\geq 60$ years.

Expression of the epidermal growth factor receptor, C-erbB-2 (Her-2-neu), positively correlated with the Ki-67 index (right-side, $r=0.27 ; \mathrm{P}<0.001$; left-side, $\mathrm{r}=0.17 ; \mathrm{P}=0.006$ ).

\section{Discussion}

Features of right-sided $\mathrm{BC}$, including the bigger size of primary tumor and more frequent metastasis in regional lymph nodes $(9,11)$, as revealed by previous studies, can be partly explained by the results of the present research. It is known that the Ki-67 index is directly connected with certain biological characteristics, including aggressive growth and metastatic potential.

Notably, the significantly higher rate of Ki-67 for the right-sided $\mathrm{BC}$, in comparison with the left-sided $\mathrm{BC}$, was observed only up until 60 years. In women who developed 
$\mathrm{BC}$ at $\geq 60$ years, lateral differences in $\mathrm{Ki}-67$ index were not observed. It is also necessary to note that, in patients with right-sided $\mathrm{BC}$, those women who became ill at $\geq 60$ years were characterized by significantly lower Ki-67 levels compared with patients of the two other age groups. This suggested a dependence of the proliferative activity of the $\mathrm{BC}$ on the functioning mechanisms and the cessation of the menstrual cycle. In the $\geq 60$ years group, Ki-67 was at a markedly low level and exhibited no lateral differences.

Results of the present study demonstrated the differences in the expression of $\mathrm{Ki}-67$ of right- and left-side tumors of the breast. Age dynamics of lateral differences of $\mathrm{Ki}-67$ in $\mathrm{BC}$ is a reflection of age dynamics of structural-functional asymmetry of a human body (25-27). In turn, asymmetry of neurohumoral regulation of the organism can be directly connected with mechanisms of the menstrual cycle (28).

\section{Acknowledgements}

The author would like to thank Dr Poroshenko for assistance in the interpretation of the results.

\section{References}

1. Fatima N, Zaman MU, Maqbool A, Khan SH and Riaz N: Lower incidence but more aggressive behavior of right sided breast cancer in pakistani women: does right deserve more respect? Asian Pac J Cancer Prev 14: 43-45, 2013.

2. Borisenkov MF and Bazhenov SM: Survival in human breast cancer: effects of tumor laterality and the time of year of surgery. Human Physiology 27: 631-634, 2001 (In Russian).

3. Bao J, Yu K-D, Jiang Y-Z, Shao Z-M, Di G-H: The effect of laterality and primary tumor site on cancer-specific mortality in breast cancer: a SEER population-based study. PLoS ONE 9: e94815, 2014

4. Aareleřd TP and Khint EK: Prevalence of tumors in the left breast. Vopr Onkol 33: 37-42, 1987 (In Russian).

5. Tulinius H, Sigvaldason H and Olafsdóttir G: Left and right sided breast cancer. Pathol Res Pract 186: 92-94, 1990.

6. Weiss HA, Devesa SS and Brinton LA: Laterality of breast cancer in the United States. Cancer Causes Control 7: 539-543, 1996.

7. Perkins CI, Hotes J, Kohler BA and Howe HL: Association between breast cancer laterality and tumor location, United States, 1994-1998. Cancer Causes Control 15: 637-645, 2004.

8. Melnik Y, Slater PE, Steinitz R and Davies AM: Breast cancer in Israel: Laterality and survival. J Cancer Res Clin Oncol 95: 291-293, 1979

9. Erendeeva LE,Zav'yalova MB,SlonimskayaEM and Perelmuter VM: Influence of functional asymmetry on the forecast of a breast cancer. Byul Sib Med 1: 36-39, 2002 (In Russian).

10. Hartveit F, Tangen M and Hartveit E: Side and survival in breast cancer. Oncology 41: 149-154, 1984.

11. Nouh MA, Ismail H, El-Din NH and El-Bolkainy MN: Lymph node metastasis in breast carcinoma: Clinicopathologic correlations in 3747 patients. J Egypt Natl Canc Inst 16: 50-56, 2004.

12. Mandard AM, Denoux Y, Herlin P, Duigou F, van De Vijver MJ, Clahsen PC, van Den Broek L, Sahmoud TM, Henry-Amar M and van De Velde CJ: Prognostic value of DNA cytometry in 281 premenopausal patients with lymph node negative breast carcinoma randomized in a control trial: Multivariate analysis with Ki-67 index, mitotic count and microvessel density. Cancer 89: 1748-1757, 2000.
13. Trihia H, Murray S, Price K, Gelber RD, Golouh R, Goldhirsch A Coates AS, Collins J, Castiglione-Gertsch M and Gusterson BA; International Breast Cancer Study Group: Ki-67 expression in breast carcinoma: Its association with grading systems, clinical parameters, and other prognostic factors-a surrogate marker? Cancer 97: 1321-1331, 2003.

14. Ponzone R, Montemurro F, Maggiorotto F, Robba C, Gregori D, Jacomuzzi ME, Kubatzki F, Marenco D, Dominguez A, Biglia N and Sismondi P: Clinical outcome of adjuvant endocrine treatment according to PR and HER-2 status in early breast cancer. Ann Oncol 17: 1631-1636, 2006.

15. Viale G, Regan MM, Mastropasqua MG, Maffini F, Maiorano E, Colleoni M, Price KN, Golouh R, Perin T, Brown RW, et al: Predictive value of tumor Ki-67 expression in two randomized trials of adjuvant chemoendocrine therapy for node-negative breast cancer. J Natl Cancer Inst 100: 207-212, 2008.

16. Penault-Llorca F, Abrial C, Raoelfils I, Cholletac P, Cayrea A, Mouret-Reynier M, Thivat E, Mishellany F, Gimbergues P and Durando $\mathrm{X}$ : Changes and predictive and prognostic value of the mitotic index, Ki-67, cyclin D1, and cyclo-oxygenase-2 in 710 operable breast cancer patients treated with neoadjuvant chemotherapy. Oncologist 13: 1235-1245, 2008.

17. Li L, Mu K, Zhou G, Lan L, Auer G and Zetterberg A: Genomic instability and proliferative activity as risk factors for distant metastases in breast cancer. Br J Cancer 99: 513-519, 2008.

18. Darb-Esfahani S, Loibl S, Müller BM, Roller M, Denkert C, Komor M, Schlüns K, Blohmer JU, Budczies J, Gerber B, et al: Identification of biology-based breast cancer types with distinct predictive and prognostic features: Role of steroid hormone and HER2 receptor expression in patients treated with neoadjuvant anthracycline/taxane-based chemotherapy. Breast Cancer Res 11: R69, 2009.

19. Sharma S, Hiran KR, Pavithran K and Vijaykumar DK: A pilot study to assess the feasibility of evaluation of markers of response to chemotherapy at one day \& 21 days after first cycle of chemotherapy in carcinoma of breast: A prospective non-randomized observational study. World J Surg Oncol 7: $35,2009$.

20. Dowsett M, A'Hern R, Salter J, Zabaglo L and Smith IE: Who would have thought a single Ki67 measurement would predict long-term outcome? Breast Cancer Res 11 (Suppl 3): S15, 2009.

21. Rodger A: Who would have thought it! Influence on outcome of radiotherapy, Ki67 and stroma. Introduction to Session 5. Breast Cancer Res 11 (Suppl 3): S13, 2009.

22. Yerushalmi R, Woods R, Ravdin PM, Hayes MM and Gelmon KA: Ki67 in breast cancer: Prognostic and predictive potential. Lancet Oncol 11: 174-183, 2010.

23. Shokouh TZ, Ezatollah A and Barand P: Interrelationships between Ki67, HER2/neu, p53, ER and PR status and their associations with tumor grade and lymph node involvement in breast carcinoma subtypes: Retrospective-observational analytical study. Medicine (Baltimore) 94: e1359, 2015.

24. Dabbs D (ed): Diagnostic Immunohistochemistry. 2nd edition. Elsevier, Philadelphia, pp699-746, 2006.

25. Jung P, Baumgärtner U, Stoeter P and Treede R-D: Structural and Functional Asymmetry in the Human Parietal Opercular Cortex. Journal of Neurophysiology 101: 3246-3257, 2009.

26. Cabeza R: Hemispheric asymmetry reduction in older adults: the HAROLD model. Psychol Aging 17: 85-100, 2002.

27. Dolcos F, Rice HJ and Cabeza R: Hemispheric asymmetry and aging: right hemisphere decline or asymmetry reduction. Neurosci Biobehav Rev 26: 819-825, 2002.

28. Poroshenko AB: About the nature of deficiency of anticancer resistance of an organism. Sbornik nauchnykh trudov RNIOI. Sposoby i mekhanizmy povysheniya protivoopukholevoi zashchity v onkologii. Moskva: 211-257, 1993 (In Russian). 